\title{
Effect on central obesity and associated disturbances of low-energy, fruit- and vegetable-enriched prudent diet in North Indians
}

\author{
Ram B. Singh, Mohammed A. Niaz and Saraswati Ghosh \\ Heart Research Laboratory, Medical Hospital and Research Centre, Moradabad, India
}

\begin{abstract}
Summary: The effects of fruit and vegetables in conjunction with low-energy diet as adjuncts to a prudent diet were compared for 6 months in a randomized, single blind trial in the management of 202 group $A$ and 204 group B patients with acute myocardial infarction. Dietary intakes were obtained based on weighing of fruit, vegetable and legume intake and weekly diet diaries. After 6 months of follow-up, mean body weight, waist/hip ratio and glucose intolerance fell significantly in patients in group A compared with those in group B. Body weight declined by $5.3 \mathrm{~kg}$ in group A versus $2.2 \mathrm{~kg}$ in group B (95\% confidence interval of difference (CI) 1.28-4.92), waist/hip ratio decreased by 0.05 in group $A$ and 0.02 in group B (95\% CI 0.01-0.10), and glucose intolerance decreased by $0.85 \mathrm{mmol} / \mathrm{l}$ in group A versus $0.19 \mathrm{mmol} / \mathrm{l}$ in group B (95\% CI 0.19-1.21). There was a significant net decrease in serum triglycerides $(0.18 \mathrm{mmol} / \mathrm{l})$, systolic and diastolic blood pressures $(7.9 / 4.7 \mathrm{mmHg})$, and a net increase in high-density lipoprotein cholesterol $(0.10 \mathrm{mmol} / \mathrm{l})$. Underlying these changes, group A patients had $393 \mathrm{~g} /$ day net increase in the consumption of fruit and vegetables and $1,160 \mathrm{~kJ} /$ day net decrease in energy intake compared to these changes in groups. Those who made greater changes in diet also had greater improvements in central obesity, glucose intolerance and in other associated disturbances.
\end{abstract}

\section{Introduction}

High rates of coronary artery disease (CAD) have been reported in urban populations of India and in people of Indian origin living outside India. ${ }^{1-6}$ It is roughly four times more common in urban compared to rural populations, which is consistent with higher fat and cholesterol intake in an urban compared to a rural population. ${ }^{1,7}$ There is evidence among South Asians in Britain of the existence of a syndrome of glucose intolerance, hyperinsulinaemia, hypertension, low plasma highdensity lipoprotein cholesterol (HDL-C) and raised triglycerides in association with central obesity. ${ }^{4,8}$ In men ${ }^{9,10}$ and women ${ }^{11}$ of European origin, central obesity is a stronger predictor of CAD than is weight for height. Hyperglycaemia or glucose intolerance have been reported to be independent predictors of CAD. ${ }^{12}$ It is possible that these metabolic risk factors are consequences of a high-energy, high-fat and high refined carbohydrate diet in populations adapted to survival under conditions of unreliable food supply and physically demanding work.

Correspondence: R.B. Singh, M.D., Heart Research Laboratory, Medical Hospital and Research Centre, Civil Lines, Moradabad-10, UP 244 001, India.

Accepted: 16 September 1993
If the above hypothesis is correct, control of obesity ${ }^{13}$ and greater physical activity ${ }^{14}$ in association with dietary changes ${ }^{15}$ are likely to be protective. We have demonstrated that a fruit- and vegetable-enriched prudent diet in association with weight loss can decrease cardiac end points within 6 weeks ${ }^{16}$ and all-cause mortality during the followup of 1 year. ${ }^{17}$ In the present paper, we report the effect of this diet on central obesity and other disturbances associated with glucose intolerance in patients after acute myocardial infarction in the randomized trial.

\section{Patients and methods}

All 505 patients admitted with a clinical diagnosis of suspected acute myocardial infarction within the previous 24 hours were considered for recruitment to this study. The details of patients and methods, exclusion criteria and criteria of diagnosis of CAD have been described elsewhere. ${ }^{16,17}$ The criteria of diagnosis of risk factors as described elsewhere ${ }^{16}$ were based on World Health Organization (WHO) criteria. ${ }^{18}$ All the patients remained in the hospital for 10-30 days. 


\section{Study design}

All the patients were randomized by the dietitian and the pharmacist after filling the consent form and assigned a diet by blindly selecting a card designated diet A or diet B from a precoded stack with an equal number of each. The responsible physician was blind to assigned dietary regimen. In both diet A and B, oils of soya bean, mustard and ground nut were substituted for foods rich in saturated fat and cholesterol such as meat, eggs, hydrogenated oils, butter and ghee to provide the 'prudent' diet. Group A patients, in addition were advised to consume at least $400 \mathrm{~g} /$ day of fruits and vegetables similar to WHO advice. ${ }^{19}$ Patients were asked to take tasty fruits and vegetables such as guava, papaya, tomato, apple, carrot, radish, cucumbers, usually in the form of salad before the major meals, to displace foods rich in energy, fat and refined carbohydrates.

Dietary advice was reinforced regularly at 1-2 weekly intervals, and each patient was individually counselled after examination of a 7-day food intake record by asking probing questions and using household measures, food models and food portions in all the participants, particularly in patients who had angina pectoris and coronary events requiring frequent medical attention. Fruit and vegetable intake was weighed at 6 months in all the patients.

\section{Data collection}

Nutrient intakes were calculated by computation of Indian food composition tables ${ }^{20}$ based on the results of dietary adherence determined by differences in the weight of fruit and vegetable intake, and weekly diet diaries in both groups. Clinical data, drug therapy and changes in risk factors were recorded regularly for 6 months by the physician blinded to dietary regimens in both groups as described earlier.$^{16,17}$ Body weights were measured at each visit by the pharmacist independently in underclothes to the nearest $0.1 \mathrm{~kg}$. Waist and hip girths were measured in the standing position. Waist was measured as the smallest horizontal girth between the costal margin and iliac crests and hip as the circumference at the level of the greater trochanters. Thigh circumference was measured as the maximum girth around the upper thigh, with the right foot resting on a chair so as to flex the hip and knee to right angles. Information obtained from the questionnaires filled to assess adherence to diet was quantified by a formula. A total score of one indicated sufficient adherence and zero indicated no adherence. Patients who adhered to more than our minimal recommendation of $400 \mathrm{~g}$ per day of fruits, vegetables, and legumes and lost more than $0.5 \mathrm{~kg}$ of body weight achieved a score greater than one. Those consuming less than our recommended amount were given a score between zero and one. These scores were converted into percentages by multiplying by 100 .

A venous blood sample after overnight fast was drawn at entry, at 6 weeks and then after 6 months from all participants and analysed for blood count haemoglobin, urea, glucose, total cholesterol, ${ }^{21}$ HDL-C and low-density lipoprotein cholesterol, and triglycerides. ${ }^{22}$ Post-prandial blood glucose was obtained by taking a 2-hour sample of blood after $75 \mathrm{~g}$ oral glucose in $200 \mathrm{ml}$ of water in a fasting state.

Data were analysed on the basis of intention to treat. $P$ values $<0.05$ using a two-tailed $t$-test were considered to have statistical significance. Two sample $t$-tests using analysis of variance were used.

\section{Results}

Of 505 patients who entered the trial in a period of 3 years, 99 were excluded. Exclusion criteria were: disliking the intervention diet $(n=12)$; presence of cancer, diarrhoea, dysentery and blood urea greater than $40 \mathrm{mg} / \mathrm{dl}(n=25)$; death before randomization $(n=20)$; and non-cardiac chest pain $(n=42)$. Of the remaining 406 patients, 204 (meam age $50.5 \pm 9.3$, year) received the cardiovaso protective diet (group A) and 202 (mean age $52.0 \pm 8.3$ years) the prudent diet (group B). A entry to the study, risk factors such as male sex, $(89.2 \%$ versus $91.5 \%)$, mean blood pressures, lipoproteins and percentage of risk factors were comparable between groups A and B. ${ }^{16,17}$ Smoking $(36.2 \%$ versus $34.6 \%)$ and alcohol intake $(22.0 \%$ versus $24.7 \%$ ) were not significantly different in group A and group B. Electrocardiographic sites of acute myocardial infarction and initial levels of cardiac enzymes were similar in both groups. The diagnosis of possible myocardial infarction $(14.8 \%$ versus $17.8 \%)$ and unstable angina $(4.9 \%$ versus $4.4 \%$ ) were also comparable between the two groups. All the patients in both groups A and B entered the trial within $24-48$ hours of infarction and the majority of the patients $(81 \%$ versus $83 \%)$ left the hospital by the 11 th day. Drug therapy at entry to study was also comparable.

After 6 months, group A patients ate higher amounts of soluble fibre and carbohydrates, and lower total and saturated fat and cholesterol as shown in Table I. In group B, nutrient intake at 6 months was comparable with nutrient intake before myocardial infarction except for a significant decrease in the consumption of dietary cholesterol with a little modified diet at 4,8,12 and 24 weeks. ${ }^{16,17}$ Group A patients also received more mustard and soya bean oils and fish, which are rich sources of omega- 3 fatty acids. Total adherence 
Table I Energy and nutrient intakes (expressed as mean (s.d.)) before entry and effect of dietary advice on nutrient intakes in participants receiving $\operatorname{diet} \mathrm{A}$ and diet $\mathrm{B}$ after 6 months

\begin{tabular}{|c|c|c|c|c|c|}
\hline & \multicolumn{2}{|c|}{ Pre-entry } & \multicolumn{2}{|c|}{$\begin{array}{c}\text { Change after } \\
24 \text { weeks } \dagger\end{array}$} & \multirow[b]{2}{*}{$\begin{array}{l}\text { Net change } \\
(95 \% C I)\end{array}$} \\
\hline & $\begin{array}{l}\text { Group A } \\
(\mathrm{n}=204)\end{array}$ & $\begin{array}{l}\text { Group B } \\
(\mathrm{n}=202)\end{array}$ & $\begin{array}{l}\text { Group A } \\
(\mathrm{n}=204)\end{array}$ & $\begin{array}{l}\text { Group B } \\
(\mathrm{n}=202)\end{array}$ & \\
\hline Total energy (kJ/day) & $8,829(732)$ & $9,010(780)$ & $-1,238$ & -78 & $\begin{array}{c}1,160^{*} \\
(882.9-1,588.1)\end{array}$ \\
\hline $\begin{array}{l}\text { Total fruit and } \\
\text { intake (g/day) }\end{array}$ & $172(23.5)$ & $165(18.8)$ & 418 & 25 & $\begin{array}{c}393^{*} \\
(351.1-434.9)\end{array}$ \\
\hline $\begin{array}{l}\text { Carbohydrate (\% kcal/ } \\
\text { day) }\end{array}$ & $58.5(0.91)$ & $59.0(0.88)$ & 3.7 & -1.9 & $\begin{array}{c}5.6^{*} \\
(4.4-6.8)\end{array}$ \\
\hline Protein (\% kcal/day) & $15.5(0.65)$ & $16.9(0.63)$ & -2.2 & -2.4 & $\begin{array}{c}0.2 \\
(-0.8-1.2)\end{array}$ \\
\hline Total fat ( $\% \mathrm{kcal} /$ day $)$ & $26.0(0.53)$ & $24.1(0.52)$ & -1.5 & 4.3 & $\begin{array}{c}5.8^{*} \\
(4.7-6.8)\end{array}$ \\
\hline $\begin{array}{l}\text { Saturated fat (\% kcal/ } \\
\text { day) }\end{array}$ & $10.0(0.39)$ & $10.0(0.38)$ & -2.5 & -0.5 & $\begin{array}{c}2.0^{*} \\
(1.2-4.0)\end{array}$ \\
\hline $\begin{array}{l}\text { Polyunsaturated/ } \\
\text { saturated fat ratio }\end{array}$ & $0.67(0.04)$ & $0.65(0.04)$ & 0.47 & 0.18 & $\begin{array}{c}0.29 * \\
(0.1-0.5)\end{array}$ \\
\hline$n-6 / n-3$ fat ratio & $7.8(1.2)$ & $7.6(1.1)$ & -3.8 & -1.2 & $\begin{array}{c}2.6^{*} \\
(1.5-4.2)\end{array}$ \\
\hline Cholesterol (mg/day) & $200.0(20.6)$ & $210.0(24.2)$ & -139.5 & -67.7 & $\begin{array}{c}71.8^{*} \\
(58.6-85.0)\end{array}$ \\
\hline Total fibre (g/day) & $27.0(10.5)$ & $25.1(10.1)$ & 23.8 & 1.1 & $\begin{array}{c}22.7^{*} \\
(15.9-29.5)\end{array}$ \\
\hline Soluble fibre (g/day) & $14.4(3.8)$ & $14.0(3.5)$ & 26.9 & 2.4 & $\begin{array}{c}24.5^{*} \\
(17.1-31.9)\end{array}$ \\
\hline Alcohol (g/week) & $44.4(16.4)$ & $42.1(13.8)$ & -20.6 & -14.5 & $\begin{array}{c}6.1^{*} \\
(-0.8-13.0)\end{array}$ \\
\hline Salt (g/day) & $7.6(1.2)$ & $8.2(1.4)$ & -2.1 & -1.1 & $\begin{array}{c}1.0^{*} \\
(0.1-1.9)\end{array}$ \\
\hline
\end{tabular}

Statistical significance by two-sample $t$-test using one way analysis of variance by comparison of changes in group $\mathrm{A}$ and $B$ after 6 months. ${ }^{*} P<0.001 ; \dagger$ at 24 weeks, dietary intake data were available for 180 group A and 170 group B patients; $\mathbf{C I}=$ confidence interval.

score to diet, reduction of alcohol intake and cessation of smoking was significantly higher in group A, than in group B (Table I). Of 406 patients initially randomized, six in group $A$ and five in group B were completely lost during the follow-up of 6 months. However, city death records showed no information of their death. Of remaining patients, 56 group A and 58 group B missed their follow-up visits for 2-4 weeks but later joined the same group. Group A patients who missed their follow-up visits showed a substantial decrease in blood lipids, indicating their adherence to dietary advice. Side effects of group A diet were mild belching, fullness, loose stools and sore throat in a few patients.

\section{Risk factors}

Changes in risk factors at 6 weeks and 1 year have been reported elsewhere. ${ }^{16,17}$ After 6 months therapy with two dietary regimens, group A showed a greater decrease in mean body weight than group B (5.3 versus $2.2 \mathrm{~kg}$ ). There was a significantly greater reduction in waist/hip girth ratio and thigh girth ratio in group $A$ than in group B compared to initial girths (Table II). The subset of group A patients who made more changes in diet and lifestyle, and had greater adherence scores showed a greater decrease in central obesity, thigh girth and improvement in other associated disturbances as shown in Table III. This subset of patients also had greater initial waist/hip ratio than the other patients.

During hospitalization, all the patients stopped smoking. However, after discharge from hospital, 23 of 74 smokers in group $A$ and 18 of 70 in group $B$ started smoking again (3.8 cigarettes/day) during the 6 months period of follow-up.

\section{Discussion}

The Indian experiment of infarct survival is the first randomized and controlled intervention trial in 
Table II Changes in central obesity and associated disturbances after 6 months compared to baseline in the intervention (Group A) and control group (Group B)

\begin{tabular}{|c|c|c|c|c|c|}
\hline & \multicolumn{2}{|c|}{ Group $A(n=204) \dagger$} & \multicolumn{2}{|c|}{ Group B $(\mathrm{n}=202) \dagger$} & \multirow[b]{2}{*}{$\begin{array}{l}\text { Net change } \\
(95 \% \text { CI })\end{array}$} \\
\hline & $\begin{array}{c}\text { Baseline } \\
\text { mean (s.d.) }\end{array}$ & $\begin{array}{l}\text { Mean } \\
\text { change }\end{array}$ & $\begin{array}{c}\text { Baseline } \\
\text { mean (s.d.) }\end{array}$ & $\begin{array}{l}\text { Mean } \\
\text { change }\end{array}$ & \\
\hline $\begin{array}{l}\text { High-density lipo- } \\
\text { protein cholesterol } \\
(\mathrm{mmol} / \mathrm{l})\end{array}$ & $\begin{array}{l}1.15 \\
(0.29)\end{array}$ & +0.07 & $\begin{array}{c}1.10 \\
(0.25)\end{array}$ & -0.03 & $\begin{array}{c}0.10^{* *} \\
(0.06-0.14)\end{array}$ \\
\hline Triglycerides (mmol/l) & 1.94 & -0.28 & 1.97 & -0.10 & $\begin{array}{c}0.18^{* *} \\
(0.09-0.27)\end{array}$ \\
\hline $\begin{array}{l}\text { Fasting blood glucose } \ddagger \\
(\mathrm{mmol} / \mathrm{l})\end{array}$ & $\begin{array}{c}6.12 \\
(0.45)\end{array}$ & -0.74 & $\begin{array}{c}6.42 \\
(0.47)\end{array}$ & -0.19 & $\begin{array}{c}0.55^{*} \\
(0.15-1.15)\end{array}$ \\
\hline $\begin{array}{l}\text { Postprandial blood } \\
\text { glucose } \ddagger(\mathrm{mmol} / \mathrm{l})\end{array}$ & 6.83 & -0.85 & 8.78 & -0.19 & $\begin{array}{c}0.66^{*} \\
(0.19-1.21)\end{array}$ \\
\hline \multicolumn{6}{|l|}{$\begin{array}{l}\text { Blood pressures } \\
(\mathrm{mmHg})\end{array}$} \\
\hline Systolic & $\begin{array}{l}132.5 \\
(5.4)\end{array}$ & 12.3 & $\begin{array}{l}134.2 \\
(7.5)\end{array}$ & -4.4 & $\begin{array}{c}7.9^{* *} \\
(4.58-11.2)\end{array}$ \\
\hline Diastolic & $\begin{array}{l}85.3 \\
(2.6)\end{array}$ & -8.1 & $\begin{array}{l}88.4 \\
(4.2)\end{array}$ & -3.4 & $\begin{array}{c}4.7 * * \\
(2.1-7.31)\end{array}$ \\
\hline Body weight (kg) & $\begin{array}{l}66.6 \\
(10.5)\end{array}$ & -5.3 & 65.3 & -2.2 & $\begin{array}{c}3.1^{* *} \\
(1.28-4.92)\end{array}$ \\
\hline Waist/hip girth ratio & $\begin{array}{l}0.95 \\
(0.05)\end{array}$ & -0.05 & $\begin{array}{c}0.94 \\
(0.04)\end{array}$ & -0.02 & $\begin{array}{c}0.03^{*} \\
(0.01-0.10)\end{array}$ \\
\hline Thigh girth $(\mathrm{cm})$ & $\begin{array}{l}56.1 \\
(8.2)\end{array}$ & -1.22 & $\begin{array}{l}55.6 \\
(7.0)\end{array}$ & -0.22 & $\begin{array}{c}1.0^{*} \\
(0.76-1.82)\end{array}$ \\
\hline
\end{tabular}

$P$ values were obtained by analysis of variance (two sample $t$-test) by comparison of changes in group A and B ${ }^{*} P<0.01 ;{ }^{* *} P<0.001 ; \dagger$ at 24 weeks laboratory data were available for 182 group $A$ and 179 group $B$ patients; $\ddagger$ at weeks; $\mathbf{C I}=$ confidence interval.

Table III Changes in central obesity and associated disturbances after 6 months compared to baselines within intervention group $\mathbf{A}$ in relation to total adherence score and weight loss

\begin{tabular}{|c|c|c|c|c|c|}
\hline & \multicolumn{2}{|c|}{$\begin{array}{l}\text { Total adherence score } \\
\quad(\text { mean }=141.5)\end{array}$} & \multicolumn{2}{|c|}{$\begin{array}{l}\text { Total adherence score } \\
\quad(\text { mean }=88.2)\end{array}$} & \multirow[b]{2}{*}{$\begin{array}{l}\text { Net change } \\
(95 \% C I)\end{array}$} \\
\hline & $\begin{array}{l}\text { Baseline } \\
(\mathrm{n}=12) \dagger\end{array}$ & $\begin{array}{c}\text { Change } \\
(\mathrm{n}=12) \dagger\end{array}$ & $\begin{array}{l}\text { Baseline } \\
(\mathrm{n}=83) \dagger\end{array}$ & $\begin{array}{c}\text { Change } \\
(\mathrm{n}=83) \dagger\end{array}$ & \\
\hline Body weight (kg) & $68.5(5.4)$ & -6.2 & $64.2(4.2)$ & -2.8 & $\begin{array}{c}3.4^{*} \\
(1.3-6.5)\end{array}$ \\
\hline $\begin{array}{l}\text { High-density lipo- } \\
\text { protein cholesterol } \\
(\mathrm{mmol} / \mathrm{l})\end{array}$ & $1.14(0.25)$ & +0.08 & $1.17(0.29)$ & -0.04 & $\begin{array}{c}0.12^{* *} \\
(0.08-0.16)\end{array}$ \\
\hline Triglycerides (mmol/l) & $2.03(0.24)$ & -0.34 & $1.85(0.19)$ & -0.15 & $\begin{array}{c}0.19 * * \\
(0.07-0.37)\end{array}$ \\
\hline $\begin{array}{l}\text { Fasting blood glucose } \\
(\mathrm{mmol} / \mathrm{l}) \ddagger\end{array}$ & $6.64(0.52)$ & -0.95 & $6.00(0.41)$ & -0.61 & $\begin{array}{c}0.36^{*} \\
(0.89-0.76)\end{array}$ \\
\hline $\begin{array}{l}\text { Post-prandial blood } \\
\text { glucose }(\mathrm{mmol} / \mathrm{l}) \ddagger\end{array}$ & $7.84(1.33)$ & -1.00 & $6.51(1.0)$ & -0.70 & $\begin{array}{c}0.30^{*} \\
(0.07-0.65)\end{array}$ \\
\hline \multicolumn{6}{|l|}{$\begin{array}{l}\text { Blood pressures } \\
(\mathrm{mmHg})\end{array}$} \\
\hline Systolic & $136.4(7.5)$ & -16.6 & $128.5(9.6)$ & -6.6 & $\begin{array}{c}10.0^{*} \\
(2.6-17.4)\end{array}$ \\
\hline Diastolic & $86.8(3.1)$ & -10.3 & $84.2(5.1)$ & -5.3 & $\begin{array}{c}5.0^{*} \\
(0.4-9.6)\end{array}$ \\
\hline $\begin{array}{l}\text { Waist/hip girth } \\
\text { ratio }\end{array}$ & $0.98(0.12)$ & -0.08 & $0.91(0.04)$ & -0.02 & $\begin{array}{c}0.06^{*} \\
(0.02-0.09)\end{array}$ \\
\hline Thigh girth $(\mathrm{cm})$ & $58.2(9.6)$ & -3.12 & $55.6(6.5)$ & -1.21 & $\begin{array}{c}1.91^{*} \\
(0.88-2.6)\end{array}$ \\
\hline
\end{tabular}

${ }^{*} P<0.05 ; * * P<0.001 ; \dagger$ at 24 weeks, labora
a lower total adherence score; $\ddagger$ at 6 weeks. 
patients with recent myocardial infarction in which intervention with a low-energy diet, enriched in fruit and vegetables as well as a soya bean and mustard oils, has been used to determine its effect on central obesity and glucose intolerance. The present experiment showed that the intervention programme with fruit and vegetables, and a lower energy diet is safe and compatible with drug therapy of myocardial infarction. After 6 months follow-up, group A patients showed a significant decrease in waist/hip girth ratio, thigh girth and post-prandial blood glucose, resulting in significant reduction in central obesity and glucose intolerance (Table II). The improvement in other disturbances associated with insulin resistance consisting of a $0.18 \mathrm{mmol} / 1 \mathrm{net}$ reduction in serum triglycerides, $0.10 \mathrm{mmol} / \mathrm{l}$ net increase in HDL-C and 7.9 / $4.7 \mathrm{mmHg}$ net decrease in blood pressure with a $393 \mathrm{~g} /$ day net increase in fruit and vegetable intake, $1,160 \mathrm{~kJ} /$ day net decrease in energy intake, and $3.1 \mathrm{~kg}$ net decrease in mean body weight in group $\mathrm{A}$ compared with group B indicates that intervention with diet ${ }^{15}$ and weight loss ${ }^{13}$ may have also caused a decline in insulin resistance, although we could not measure the plasma level of insulin. Within group A, a subset which had frank central obesity, the patients made greater changes in diet resulting in greater reduction in central obesity and other associated disturbances (Table III). Soya bean and mustard oil, due to their increased content of linolenic acid, are known to reduce glucose intolerance and insulin resistance. ${ }^{7}$

In one study among Indian immigrants, ${ }^{4,23} \mathrm{a}$ high prevalence of diabetes was associated with a pronounced tendency to central obesity. Mean waist/ hip girth ratio was higher and trunk skin folds were thicker in South Asian men than in Europeans without corresponding ethnic differences in body mass index or thigh skin folds. Thigh girth in South Asian men was significantly less than in Europeans (55.4 versus $56.7 \mathrm{~cm})$. In Australians, ${ }^{24}$ waist $/ \mathrm{hip}$ ratio was 0.90 and body mass index $26.6 \mathrm{~kg} / \mathrm{m}^{2}$, which is similar to Europeans. South Asian men do not seem to have more fat on the hips and thighs than European men. ${ }^{23}$ In our study, the thigh circumferences in group A and B were comparable with South Asian men in Britain (56.1, 55.6 and $55.4 \mathrm{~cm}$, respectively) and waist/hip ratio was less $(0.95,0.94$ and 0.98 , respectively). Body mass index

\section{References}

1. Chadda, S.L., Radhakrishnan, S., Ramchandran, K., Kaul, U. \& Gopinath, N. Epidemiological study of coronary heart disease in urban population of Delhi. Ind J Med Res 1990, 92: 424-430.

2. Balrajan, R. Ethnic differences in mortality from ischaemic heart disease and cerebrovascular disease in England and Wales. Br Med J 1991, 302: 560-564. in our group A and B patients was also less than in South Asian men $\left(24.3,23.3\right.$ and $\left.25.7 \mathrm{~kg} / \mathrm{m}^{2}\right)$, which may be due to higher mean body weight but the same height in South Asian immigrants (66.6, 65.3 and $73.8 \mathrm{~kg}$ ). It is clear that abdominal obesity in Indians is not as marked as in Indian immigrants to Britain. However, the mean age for developing myocardial infarction in Indians was similar to South Asians but less than in Europeans (51.2, 50.7 and 61.8 years), indicating that Indians all over the world possibly develop CAD at a younger age than Western populations. ${ }^{3,4,8,25}$ There is a need for a more reliable method to measure waist/hip ratio. In one study, ${ }^{26}$ waist was measured as the least circumference between the level of xiphisternum and the umbilicus, which is uncertain. In the Australian study, ${ }^{24}$ waist was measured at the level of umbilicus.

Diet and lifestyle changes in Indians are of more recent origin than in Western populations, which may have allowed the European populations to adapt successfully. ${ }^{7}$ However, decreased physical activity in conjunction with rapid increase in the consumption of energy-rich refined foods and fat may not allow the physiological mechanisms to either 'burn' or distribute the fat proportionately to different parts of the body, resulting in central obesity. Intra-abdominal fat cells are resistant to insulin-mediated suppression of lipolysis and release of non-esterified fatty acids into the portal circulation. ${ }^{25}$ Thus central obesity, a sedentary lifestyle and manufactured foods each may have independently contributed to insulin resistance, glucose intolerance and other disturbances among Indian immigrants. ${ }^{7}$ It seems that the intervention programme used in the present trial addresses all of the dietary factors ${ }^{13-15}$ and therefore decrease in risk factors should cause a decline in CAD. ${ }^{17}$ Although a decrease in plasma insulin should be demonstrated in association with decrease in central obesity to confirm the efficacy of this approach, our diet containing $600 \mathrm{~g} /$ day of fruit and vegetables in conjunction with a low-energy prudent diet may be advised for prevention of CAD among South Asians. ${ }^{17,27}$

\section{Acknowledgement}

We thank Vipin Gupta for secretarial help.

3. Enas, E.A., Yusuf, S. \& Mehta, J.L. Prevalence of coronary artery disease in Asian Indians. Am J Cardiol 1992, 70: 945-949.

4. McKeigue, P.M. Coronary heart disease in Indians, Pakistanis and Bangladeshis; aetiology and possibilities for prevention. Br Heart J 1992, 67: 341-342. 
5. Sarvotham, S.G. \& Berry, J.N. Prevalence of coronary heart disease in an urban population in northern India. Circulation 1968, 37: 939-953.

6. Malhotra, S.L. Epidemiology of ischaemic heart disease in India with special references to Caucasians. Br Heart J 1967 , 29: 895-905.

7. Singh, R.B., Mori, H., Kokatnur, M. \& Kummerow, F.A. Nutrition in Coronary Heart Disease. International College of Nutrition Monograph, Moradabad, 1991.

8. Hughes, L.O., Cruickshank, J.K., Wright, J. \& Reftery, E.B. Disturbances of insulin in British Asian and White men surviving myocardial infarction. $\mathrm{Br} \mathrm{Med} J$ 1989, 299: 537-541.

9. Donahae, R.P., Abbott, R.D., Bloom, E., Reed, D.M. \& Yano, K. Central obesity and coronary heart disease in men. Lancet 1987, 1: 821-824.

10. Ducimetiere, P., Richard, J. \& Cambien, F. The pattern of subcutaneous fat distribution in middle-aged men and the risk of coronary heart disease: the Paris prospective study. Int J Obesity 1986, 10: 229-240.

11. Lapidus, L., Bengtsson, C., Larsson, B., Pennert, K., Rybo, E. \& Sjostrom, L. Distribution of adipose tissue and risk of cardiovascular disease and death: a 12 year follow up of participants in the population study of women in Gothenburg. Br Med J 1984, 289: 1257-1261.

12. Wilson, P.W.F., Cupples, L.A. \& Kannel, W.B. Is hyperglycemia associated with cardiovascular disease? The Framingham Study. Am Heart J 1991, 121: 586-589.

13. Olefsky, J.M., Reaven, G.M. \& Farquhar, J.W. Effects of weight reduction on obesity: studies of carbohydrate and lipid metabolism. J Clin Invest 1974, 53: 64-76.

14. Kiovisto, V.A., Yki-Jarvinen, H. \& Defronzo, R.A. Physical training and insulin sensitivity. Diabetes Metab Rev 1986, 1: 445-481.

15. Oettle, G.J., Emmett, P.M. \& Heaton, K.W. Glucose and insulin responses to manufactured and whole food snacks. Am J Clin Nutr 1987, 45: 86-91.

16. Singh, R.B., Rastogi, S.S., Verma, R., Bolaki, B. \& Singh, R. An Indian experimental with nutritional modulation in acute myocardial infarction. Am J Cardiol 1992, 69: 879-885.
17. Singh, R.B., Rastogi, S.S., Verma, R. et al. Randomized controlled trial of cardioprotective diet in patients with recent acute myocardial infarction: results of one year follow-up. $\mathrm{Br}$ Med J 1992, 304: 1015-1019.

18. World Health Organization. Myocardial Infarction Community Registers. WHO, Copenhagen, 1976.

19. World Health Organization. Diet, Nutrition and Prevention of Chronic Disease. WHO, Geneva, 1990.

20. Narsinga Roa, B.S., Deosthale, Y.G. \& Pant, K.C. Nutrient Composition of Indian Foods. National Institute of Nutrition, Hyderabad, India, 1989.

21. Wilson, D.E. \& Spiger, M.J. A dual precipitation method for quantitative plasma lipoprotein measurement without ultracentrifugation. $J$ Lab Clin Med 1973, 82: 413-482.

22. Van Handel, E. \& Zilversmit, B.D. Micromethod in the direct estimation of serum triglycerides. J Lab Clin Med 1957, 60: 152-159.

23. McKeigue, P.M., Pierpoint, T., Ferrie, J.E. \& Marmot, M.G Relationship of glucose intolerance and hyperinsulinemia to body fat pattern in south Asians and Europeans. Diabetologia 1992, 35: 785-791.

24. Tienboon, R., Wahlquvist, M.L. \& Rutishausher, I.H.E. Early life factors affecting body mass index and waist-hip ratio in adolescence. Asian Pacific J Clin Med 1992, 1: 21-26.

25. Richelsen, B., Pedersen, S.B., Moller-Pedersen, T. \& Bak, J.P Regional differences in triglyceride breakdown in human adipose tissue-effects of catecholamines, insulin and prostaglandin E. Metab Clin Exp 1991, 40: 990-996.

26. Dowse, G.K., Zimmet, P.Z. \& Gareeboo, H. Abdominal obesity and physical inactivity as risk factors for noninsulindependent diabetes mellitus and impaired glucose tolerance in Indians, Creole and Chinese Mauritians. Diabet Care 1991, 14: $271-282$.

27. Singh, R.B. \& Niaz, M.A. Coronary heart disease in Indians Pakistanis and Bangladeshis: aetiology and possibilities fog prevention (letter). Br Heart J 1993, 69: 572. 